\title{
A study on behaviors of purchasing life insurance in Vietnam
}

\author{
Thi Huong Mai ${ }^{a}$, Thi Chinh Nguyen ${ }^{b}$, Le Lam Vuc ${ }^{c^{*}}$, Van Hung Bui ${ }^{b}$, Thi Thu Cuc Nguyend and \\ Duc Tai Doa
}

${ }^{a}$ University of Labor and Social Affairs, Vietnam

${ }^{b}$ National Economics University, Vietnam

${ }^{c}$ Accounting department, Faculty of Economics and Management, Thuyloi University, 175 Tay Son, Dong Da, Hanoi ,Vietnam

${ }^{d}$ Vinh University, Vietnam

\section{H R O N I C L E}

\begin{tabular}{l} 
Article history: \\
Received: October 14, 2019 \\
Received in revised format: No- \\
vember 292019 \\
Accepted: January 15, 2020 \\
Available online: \\
January 15, 2020 \\
\hline Keywords: \\
Intention, decision \\
Life insurance \\
Theory of planned behavior (TPB)
\end{tabular}

\begin{abstract}
A B S T R A C T
This research is conducted to examine the process from the intention to purchase life insurance among people in two major cities of Hanoi and Ho Chi Minh City in Vietnam, based on the theoretical framework of theory of planned behavior. The study is conducted in Hanoi and Ho Chi Minh City in Vietnam through an online questionnaire of 358 people. Based on the data collected, the study used Cronbach's alpha, exploratory factor analysis, KMO and Bartlett's test and regression analysis by using SPSS software. The results show that life insurance buying behavior was influenced by purchase intention, attitudes, financial insight and product accessibility. Moreover, it was recognized higher weight of financial literacy and product accessibility in life insurance buying behavior. The research determined that financial knowledge could promote buying intention to actual purchase behavior in the life insurance area.
\end{abstract}

\section{Introduction}

Life insurance is one of the insurance types which was born quite early with the original purpose of covering life and death events for customers. Nowadays, based on the basic characteristics of savings and risk as well as traditional products, life insurance products are increasingly diverse to meet different goals of insures in terms of consumption, savings and risk management. At the same time, objectives, goals and coverage of these products are also increasingly expanded towards effective financial plans for participants from birth to retirement. Despite great benefits and multiple purposed adaption of life insurance, as well as the economic growth and consumer income increase, the life insurance market has not been proportionally increasing. Vietnam is one of the "youngest" markets as assessment of insurance groups such as AIA with 70\% of the population under the age of 35 , the emerging middle class currently accounts for $13 \%$ of the population and is expected to reach $26 \%$ by 2026 . The rapid change in population structure as well as the increasing of middle-class society offers many opportunities for life insurance companies, boosting demand for health insurance and quality improvement products. However, according to the data of Swiss Re in 2017, the rate of participation in life insurance of developed countries such as the United Kingdom, the United States and Japan is over 90\%; in regional countries like Singapore, is over $80 \%$; Malaysia's is $50 \%$ while this rate in Vietnam as of 2017 is only about $10 \%$. Hanoi and Ho Chi Minh City are known as the two largest cities in Vietnam with relatively high population and living standards, but the rate of participation in life insurance is still very low compared with other countries in the countries in the area as mentioned above. Therefore, the study of determinants affecting the life insurance purchasing process including intentions and behaviors of people in these two cities can give lessons for 
other countries in the region to improve the growth rate of the life insurance market in general and raising the level of social security for people actively. In addition, this study will contribute to proposing solutions for insurance enterprises in Vietnam to promote the purchase of life insurance in this area.

\section{Literature review}

There have been plenty of researches on life insurance in general as well as the intention to buy life insurance or the demand for life insurance which were conducted all over the world. Life insurance allows individuals and households to share with others and support financial losses from undesirable risks such as death from their basic salary (Garman \& Forgue, 2006). Life insurance is an important financial tool for allocating resources against uncertain events in life (Yaari, 1964; Yaari, 1965) and is an important component of a long-term financial plan (Carson \& Forster, 2000). These studies also indicate that there are many determinants that influence customers' intention and needs to buy life insurance, including economic, psychological or cultural, and social determinants. Prior studies concentrate on the (i) traditional theoretical frameworks; (ii) behavioral perspectives.

\subsection{Traditional theoretical frameworks}

The researches that can be mentioned in this direction include: the theory of life insurance model originated by Yaari (1964); Yaari (1965), Campbell (1980), Lewis (1989) and Fischer (1973). All of these studies are based on the expected utility theory (EUT) proposed by Morgenstern and Von Neumann (1953). Accordingly, insurance needs are determined based on maximizing expected benefits based on a number of determinants such as age, life expectancy, income in relation to risk aversion. Berekson (1972), Baek and Devaney (2005a), Showers and Shotick (1994) have found that the influence of age has a positive and sufficient impact but the result of Chen (2009) shows a negative relationship between age and the need of life insurance. Besides, Hammond et al. (1967) and Baek and Devaney (2005b) agreed in their studies that there was a positive correlation between educational attainment and demand for life insurance. They suggested that those with a higher educated level would buy more life insurance. In addition, the effect of current income on life insurance needs is examined in numerous studies Hwang and Gao (2003), Li et al. (2007) and Beck and Webb (2003) also state that income is positively associated with the demand for life insurance. The study of synergistic effects has produced heterogeneous results due to differences in cultural, psychological as well as socio-economic conditions in different regions. Therefore, when empirical research became more popular in economics as well as research from the behavioral model was strengthened, the decision to buy life insurance from a behavioral perspective has been developed (Starmer, 2000)

\subsection{Behavioral perspectives}

\section{Studies based on Theory of Reasoned Action (TRA)}

Hastings and Fletcher (1983); Ogenyi Ejye and Owusu-Frimpong (2007) applied the model of Fishbein and Ajzen (1980) with the belief that life insurance purchasing behavior (B) could be predicted by intent to act (BI) and in order to test the relevance of TRA model in the insurance sector. Accordingly, this intention of behavior can be explained by Attitude toward behavior (Aact) and social influence or subjective norms (SN). Attitude toward behavior (Aact) can be explained by an understanding of a person's outstanding beliefs about the results of taking action (bi) and his assessments of his beliefs (ei). The subjective norms can be explained by one's knowledge of the beliefs about some important people who think that they should or should not take action (NBi) along with their motivation to comply. This is consistent with the model's view that actual behaviors may be determined by intended behaviors, but these studies have not considered the determinants that prevent or facilitate the insurance decisions or motivating determinants from intention to life insurance buying behavior (Kasule, 2011).

\section{Studies based on Theory of planned behavior (TPB)}

Brahmana et al. (2018) overcame these limitations by considering the act of buying insurance according to the TPB model (Ajzen, 1980, Ajzen, 1991) as well as applying the recently developed theoretical framework to consider the process that takes place from intent to act with the effect of attitude variables on behavior (Ajzen \& Fishbein, 2005) related to the decision to buy personal health insurance. The four main variables of TPB include attitudes to behavior (ATB), subjective norms (SN), Perceived behavioral control (PBC) and intent. The theory of planned behavior (TPB) can explain the psychological control process of buying insurance. The need for insurance is driven by attitudes toward subjective norms of pursuit (environmental and social impacts) and awareness of behavioral control. In addition, the "health" variable added to the model acts as a moderator variable to consider the motivating process from Indonesia's intention to purchase personal health insurance. This study is an important contributor to insurance research. Unlike previous studies, this research has successfully introduced the role of psychologists to promote the purchase of life insurance. Therefore, with the development of the theory of behavioral economics, understanding the process of buying life insurance from the perspective of the decision-making process, especially from the perspective of buying behavior theory such as: Recent studies of Brahmana et al. (2018) and Omar (2007) are absolutely necessary and consistent with the current trend. In the context of Vietnam, there are many researches on this topic at different levels, however, the exploitation has just stopped at the research from a market perspective (Trong Thao Phi, 2003; Thuy Tien Ho, 2007). The research of market development and customer satisfaction is important because it helps promote the development of the economy in general, but in order to achieve this, it must be based on a very important decision: Whether or not customers will buy life insurance products. There have been some articles studied from personal perspective such as 
Tien Dung Nguyen et al. (2015) on voluntary pension insurance products of residents of Ho Chi Minh City. This study also focuses on intentions rather than buying behavior. In addition, the process from buying intent to actual buying behavior has not been considered. Therefore, based on the analysis of the overall research results and considering the suitability of the theoretical basis, the authors found that it is appropriate to apply the planned behavioral theory of Ajzen and Fishbein (2005); Ajzen and Cote (2008)) with the most recent studies relating to the relationship between attitudes, intentions and behaviors our studying the decision to buy personal life insurance products. Accordingly, the focus of this study is to examine determinants that influence the process from intent to actual buying behaviors. As suggested by Ajzen and Fishbein (2005), behavioral control determinants will be included in the model that act as independent variables affecting intention and buying behavior, as well as regulatory variables which can promote (or obstruct) the intention to purchase into actual buying behavior.

\section{Research methodology}

This study selected Hanoi and Ho Chi Minh City as the study area because these two cities are known as two of the most densely populated cities and have significant economic growth in Vietnam. However, the number of people buying life insurance is not as expected. The research results of Hanoi and Ho Chi Minh City may become typical for emerging economic regions in the region. As the purpose of testing a number of hypotheses which are generated from previous existing theories to prove the relationship between particular variables, this research is collecting quantitative data to test the hypotheses. This research is applying non-probability sampling technique as the respondents are selected by the author based on some certain criteria. The questionnaire was designed based on the theories introduced in the literature review. It includes 25 observation variables with a 5 -point Likert scale. All the items used in each part are adopted from the validated scales of previous studies by Ajzen (2006), Jacoby and B. Kaplan (1972), Brahmana et al. (2018) and Vu Hung Nguyen et al. (2016). Based on the literature review, by inheriting the research of Mekonin (2018), the conceptual model research framework of this study is depicted in Fig. 1.

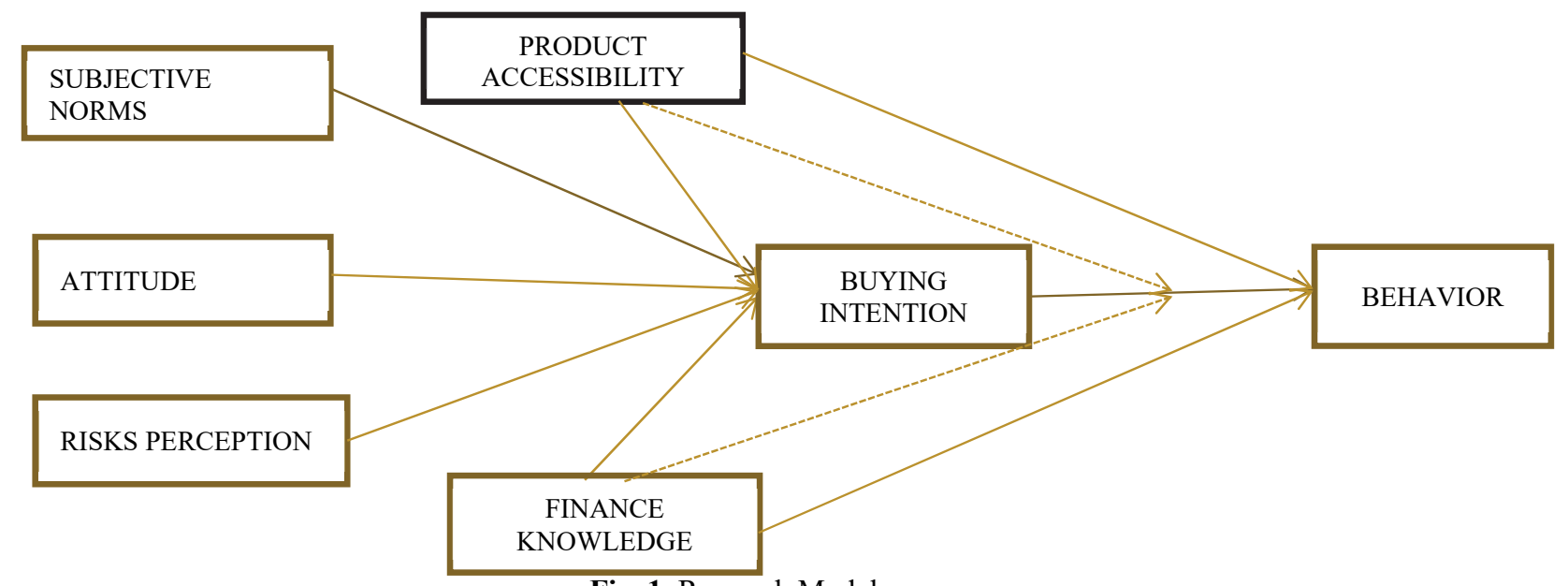

Fig. 1. Research Model

The research model is designed to examine the relationship between determinants to the intention and decision to buy life insurance. In addition, the behavioral control variable according to the rational action theory (TPB) is included in the model which is concretized into "financial Knowledge" and "product accessibility" will serve as both an independent and a moderator variable in the model to examine the relationship from intention to insurance purchase behavior of customers. The collected data will be analysed by the SPSS statistical analysis software. Since this study aims to examine the influence of determinants on the decision to buy life insurance, the research hypotheses to be discussed include:

$\mathrm{H}_{1}$ : Insurance attitude positively affects the intention to buy life insurance.

$\mathrm{H}_{2}$ : Subjective norms positively influence the intention to buy life insurance.

$\mathrm{H}_{3}$ : Risk perception positively affects the intention to buy life insurance.

$\mathrm{H}_{4}$ : Financial knowledge positively affects the intention to buy life insurance.

$\mathrm{H}_{5}$ : Product accessibility positively affects the intention to purchase life insurance.

$\mathrm{H}_{6}$ : The intention to buy life insurance positively influences the decision to buy life insurance.

$\mathrm{H}_{7}$ : Financial Knowledge positively affects the decision to buy life insurance.

$\mathrm{H}_{8}$ : Product accessibility positively affects life insurance purchasing decisions.

$\mathrm{H}_{9}$ : Product accessibility has the effect of promoting the intention to purchase life insurance.

$\mathrm{H}_{10}$ : Financial Knowledge has the effect of promoting the intention to buy life insurance.

After finishing the online survey process, there were 400 responses collected but there were only 358 responses counted as the valid observations to be examined further in this research. 


\section{Research results}

According to the statistics of the Insurance Administration and Supervision Department (ISI, 2019), the amount of life insurance premium revenue for both main and auxiliary products is VND 115982 billion but compared with Vietnam's GDP in 2018 , this number only reached $2.09 \%$ penetration (GSO, 2018). In addition, the ratio of fee revenue per capita of Vietnam is still low as 1,226 million VND / person while the current income per capita in GDP of Vietnam is 58,587 million VND / person. The number of new insurance policies on the market in 2018 is 2,248,157, the number of main insurance policies as of the end of the period is $8,677,911$. The total number of insurance policies for both main products and riders by the end of 2018 is $25,196,252$ policies, compared to the current Vietnamese population of $94,600,000$, the average percentage of the population having life insurance only reached $9.17 \%$ (ISI, 2019). This means that although achieving a high growth rate of $30.34 \%$ (ISI, 2019), this rate is still not commensurate with the developing potential of the insurance market in Vietnam. Therefore, the results of determinant analysis are expected.

By using SPSS software, the results of this research are shown in details below:

\section{Descriptive analysis}

As the information of demographics is collected in the first part of questionnaire, it is analyzed into general statistical form to see the breakdown of frequency and percentage of each control variables. Descriptive analysis is applied to aggregate the overall respondents' profiles. Table 1 gives the information of the descriptive analysis.

Table 1

Demographic characteristics of Respondents

\begin{tabular}{|c|c|c|c|c|c|c|c|}
\hline Variables & Category & Frequency & Percentage (\%) & Variables & Category & Frequency & Percentage (\%) \\
\hline \multirow{2}{*}{ Gender } & Male & 196 & 54.7 & \multirow{4}{*}{ Educational } & High school & 32 & 8.9 \\
\hline & Female & 162 & 45.3 & & Graduated & 188 & 52.5 \\
\hline \multirow{4}{*}{ Age } & $20-30$ & 49 & 13.7 & & Colleges & 93 & 26 \\
\hline & $31-40$ & 188 & 52.5 & & Post graduated & 45 & 12.6 \\
\hline & $41-50$ & 90 & 25.1 & \multirow{4}{*}{ Income } & Under 9 million & 32 & 8.9 \\
\hline & above 50 & 31 & 8.7 & & $9-15$ & 161 & 45.0 \\
\hline \multirow{2}{*}{$\begin{array}{l}\text { Buying Life } \\
\text { insurance }\end{array}$} & Having life insurance & 90 & 25.1 & & $15-20$ & 80 & 22.3 \\
\hline & Haven't had life insurance & 268 & 74.9 & & Above 20 & 30 & 8.4 \\
\hline
\end{tabular}

From the descriptive analysis, we can see that:

Genders: The results show that 166 male and 176 female participants responded to the questionnaire. The number of women is higher but not significant (54.7\% and $45.3 \%)$. The gender gap in this survey is consistent with statistics of the population in the whole country from the official Report on Labor Force Survey on Ministry of Planning and Investment of Vietnam 2018.

Age: According to the analysis results, the number of surveyed people aged from 31 to 40 years old accounts for the largest proportion. The second is from 41 to 50 years old, the third from 20 to 30 and the last is from 50 years old. The age structure of the surveyed subjects is similar to the potential buyers of insurance that insurance enterprises need to exploit.

Education level: According to the table of education structure, we see the highest proportion of people belonging to graduated and college. This figure also reflects the educational level of Hanoi area with the majority of intellectual and business labor.

Income: From the interview data, it can be seen that the highest proportion of income is in the range of 9-15 million (45\%). Since these are the two major cities of Vietnam, this income level is considered appropriate for the scope of the study. At the same time, this rate also shows that in reality, people's income is not too low, but the rate of buying insurance is still limited. Therefore, determinant analysis is expected to produce significant results.

Buying status: According to the survey data on the status of purchasing life insurance of the surveyed participants, $74.9 \%$ of the respondents have never purchased a life insurance and only $25.1 \%$ of the respondents having life insurance.

Cronbach's Alpha - Reliability

In order to conduct the reliability test, Cronbach's Alpha is used as the most popular and effective tool in SPSS analysis (Hair et al., 2010).

Table 2

Cronbach's Alpha Analysis

\begin{tabular}{|c|c|c|c|c|c|c|c|}
\hline Variables and coding & Cronbach's Alpha & Mean & No. of items & Variables and coding & $\begin{array}{c}\text { Cronbach's } \\
\text { Alpha }\end{array}$ & Mean & No. of items \\
\hline Risk perception (RP) & 0.802 & 2.558 & 4 & Product accessibility & 0.9 & 2.856 & 3 \\
\hline Attitude (ATT) & 0.801 & 2.5 & 4 & Buying Intention (BI) & 0.804 & 2.838 & 3 \\
\hline Subjective norm (SN) & 0.773 & 2.677 & 3 & Behavior $(\mathrm{BH})$ & 0.713 & 2.56 & 4 \\
\hline Finance Knowledge (FKN) & 0.886 & 2.556 & 4 & & & & \\
\hline
\end{tabular}


In this research, the Cronbach's Alpha test is applied for one dependent variable and two independent variables. Table 2 demonstrates the result of Cronbach's Alpha test. Hair et al. (2010) also note that the Cronbach's Alpha result should be equal to or higher than $0.7(\geq 0.7)$ to be reliable enough for research. The Cronbach's Alpha results in Table 2 all meet these standard requirements, which means that every item in the questionnaire has a good level of reliability and can be accepted to use for this research.

\section{Factor analysis}

George and Mallery (2016) emphasize that one of the most crucial steps when analyzing data with SPSS is Exploratory Factor Analysis (EFA), which identifies the correlation among observed variables and examine the validity of the set of items.

\section{KMO and Bartlett's Test}

In this research, the KMO and Bartlett's Test for independent variables is conducted as the result is illustrated in the Table 3. As shown, the KMO value is $0.819(0.5<0.819<1)$ and the sig. value is $0.000(<0.05)$, that means these values satisfied the conditions in the study (Hair et al., 2010). In addition, after implementing the rotation matrix, we got the followings: every determinant with factor load $>0.5$, Eigenvalues is $1.251>1$, and the Variance explained $=71.56 \%$. It demonstrates that the factor analysis of the research data is appropriate.

Table 3

The results of KMO and Bartlett's Test

\begin{tabular}{lll}
\hline Kaiser-Meyer-Olkin Measure of Sampling Adequacy. & & 0.819 \\
\hline Bartlett's Test of Sphericity & Approx. Chi-Square & $3,604.678$ \\
& Df & 210 \\
& Sig. & 0.000 \\
\hline
\end{tabular}

\section{Regression Model Analysis}

In this study, as there is more than one independent variable, a multiple regression analysis is conducted to predict the outcome change. In this research, there are 2 dependent variables, hence, the regression step will be performed with two variables, intention and behavior, respectively.

\section{Regression results with the intention as dependent variable}

To test the hypotheses $\mathrm{H}_{1}, \mathrm{H}_{2}, \mathrm{H}_{3}, \mathrm{H}_{4}, \mathrm{H}_{5}$ on the influence of determinants on the intention to buy life insurance products, research and implement the following model regression. Table 4 illustrates the validity of the model as well as the s relationships between five independent variables (predictor) with the dependent variable: Buying intention. In this model, the Rsquare value is 0.629 , which means that $62.9 \%$ the variance of Buying intention can be explained by five variables. The $\mathrm{p}$ value (sig. Value) in the ANOVA test with $95 \%$ confidence interval is 0.00 and satisfies the condition of lower than 0.05 . That is to say, the ANOVA analysis proves that the linear model is meaningful.

Table 4

Model summary 1 ( Adjusted R Square, Anova)

\begin{tabular}{llrrrr}
\hline & Model 1 & Sum of Squares & Df & Mean Square & F \\
\hline \multirow{2}{*}{1} & Regression & 148.686 & 5 & 29.737 & 122.138 \\
& Residual & 85.702 & 352 & .243 & \\
\cline { 2 - 4 } & Total & 234.389 & 357 & & \\
\hline
\end{tabular}

R-Square $=0.796^{\mathrm{a}}$ Adjusted-R-Square $=0.629$

Table 4

The results of regression analysis (Continued)

\begin{tabular}{|c|c|c|c|c|c|c|c|}
\hline \multirow{2}{*}{ Model 1} & \multicolumn{2}{|c|}{ Unstandardized Coefficients } & \multirow{2}{*}{$\frac{\text { Standardized Coefficients }}{\text { Beta }}$} & \multirow{2}{*}{$\mathrm{T}$} & \multirow{2}{*}{ Sig. } & \multicolumn{2}{|c|}{ Collinearity Statistics } \\
\hline & $\mathrm{B}$ & Std. Error & & & & Tolerance & VIF \\
\hline (Constant) & 0.452 & 0.112 & & 4.022 & 0.000 & & \\
\hline Finance knowledge & 0.361 & 0.032 & 0.455 & 11.357 & 0.000 & .646 & 1.548 \\
\hline Product accessibility & 0.109 & 0.024 & 0.17 & 4.532 & 0.000 & .735 & 1.361 \\
\hline Subjective norm & 0.007 & 0.027 & 0.097 & 2.868 & 0.004 & .913 & 1.095 \\
\hline Attitude & 0.214 & 0.032 & 0.237 & 6.633 & 0.000 & .816 & 1.226 \\
\hline Risk perception & 0.161 & 0.029 & 0.186 & 5.478 & 0.000 & .903 & 1.108 \\
\hline
\end{tabular}

In the Coefficients result shown in Table 4, all of the p-value (sig. Value) are less than 0.05 , meaning the independent variables are the significant predictors for the dependent variable. Further, the VIF values on both predictors are lower than 2, meaning there is no multicollinearity. The output supports to the correlation test as all of the variables have positive relationship on buying intention. Thence, five Hypotheses $\left(\mathrm{H}_{1}, \mathrm{H}_{2}, \mathrm{H}_{3}, \mathrm{H}_{4}, \mathrm{H}_{5}\right)$ are accepted. Based on the result, the regression equation can be established as below:

$$
\mathrm{BI}=0.455 \mathrm{FKN}+0.17 \mathrm{PA}+0.097 \mathrm{SN}+0.237 \mathrm{ATT}+0.186 \mathrm{RP}
$$


In order to analyze the impact of determinants on life insurance decision making, the research performed regression to test hypotheses $\mathrm{H}_{6}, \mathrm{H}_{7}, \mathrm{H}_{8}$. However, according to the regression results of model 1, the variables BI, FKN, PA are correlated, so before performing regression model 2, the study will perform the Mean Centering technique to eliminate multicollinearity (Hair et al., 2010, Cohen, 1988). The variables after performing mean Centering will be recoded as BI_AVER; FKN_AVER; PA_AVER. The regression analysis results from Table 5 show that intention, product access and financial understanding have some influences on the behavior of buying life insurance with the model's explanation level is 55.8\% (Adjusted R Square is $0.558>0.5)$. Thus, hypotheses $\mathrm{H}_{7}, \mathrm{H}_{7}, \mathrm{H}_{8}$ are accepted. In particular, the intention and financial knowledge are two determinants which sly influence the purchasing life insurance, product accessibility also has a positive impact on buying behavior with a beta of 0.249 .

Table 5

Model summary 2

\begin{tabular}{|c|c|c|c|c|c|c|c|}
\hline \multirow{2}{*}{\multicolumn{2}{|c|}{ Model }} & \multicolumn{2}{|c|}{ Unstandardized Coefficients } & \multirow{2}{*}{$\frac{\text { Standardized Coefficients }}{\text { Beta }}$} & \multirow[b]{2}{*}{$\mathrm{T}$} & \multirow[b]{2}{*}{ Sig. } & \multirow{2}{*}{$\begin{array}{l}\text { Adjusted R } \\
\text { Square }\end{array}$} \\
\hline & & $\mathrm{B}$ & Std. Error & & & & \\
\hline \multirow[t]{4}{*}{2} & (Constant) & 2.559 & .028 & & 89.950 & .000 & \\
\hline & FKN_AVER & .254 & .040 & 0.321 & 6.324 & .000 & .558 \\
\hline & PA_ĀVER & .159 & .027 & 0.249 & 5.908 & .000 & \\
\hline & BI AVER & .311 & .051 & 0.311 & 6.078 & .000 & \\
\hline
\end{tabular}

The process from intent to purchasing life insurance

To test the influence of two moderator variables, namely financial knowledge and product accessibility, the technique of analyzing the moderator variables Process 3.3, which proposed by Hayes (2012) is suggested to use to test hypotheses $\mathrm{H}_{9}$ and $\mathrm{H}_{10}$. The regression results in Table 6 show that the model with $\mathrm{r}$ square of $0.5989(>0.5)$ explained $59.89 \%$ larger than $r$ square of model 2 when there were no moderator variables. Hence, adding moderator variables to the model makes it more meaningful. In addition, the sig coefficients are all $0.000(<0.05)$ of all 4 variables: intention, financial knowledge, product accessibility and financial knowledge moderator variables have a positive impact on buying life insurance behavior.

Table 6

Model summary 3

\begin{tabular}{|c|c|c|c|c|c|c|}
\hline \multirow{2}{*}{\multicolumn{2}{|c|}{ Model }} & \multicolumn{2}{|c|}{ Unstandardized Coefficients } & \multirow[b]{2}{*}{$\mathrm{T}$} & & \multirow{2}{*}{$\begin{array}{r}\text { Adjusted R } \\
\text { Square }\end{array}$} \\
\hline & & $\mathrm{B}$ & Std. Error & & Sig. & \\
\hline \multirow[t]{6}{*}{3} & (Constant) & 2.4483 & .033 & 89.950 & .000 & \multirow{6}{*}{.5989} \\
\hline & FKN_AVER & .1832 & .041 & 6.324 & .000 & \\
\hline & PA_ĀVER & .1486 & .026 & 5.908 & .000 & \\
\hline & BI_AVER & .2752 & .049 & 6.078 & .000 & \\
\hline & BI_AVER × PA_AVER & -.0182 & .040 & -.4513 & .652 & \\
\hline & BI AVER $\times$ FKN AVER & .2064 & .048 & 4.303 & .000 & \\
\hline
\end{tabular}

The model results show that in the condition of the intention to buy insurance, the intention is the most powerful determinant with a beta correlation coefficient of 0.2752 . The remaining two variables, namely knowledge and accessibility of products with impact levels of 0.1832 and 0.1486 , respectively, also promote the decision to buy life insurance. Additionally, when considering two moderator variables, the regression results show that only financial knowledge can influence the process from intent to actual behavior (accept hypothesis $\mathrm{H}_{10}$ ). Meanwhile, product accessibility is not due to sig. $=0.652>0.05$ (rejected hypothesis H9). The research conducting to run regression removing a PA moderator variable achieved the following results:

Model 3: $\mathrm{BH}=0.277 \times \mathrm{BI} \_A V E R+0.232 \times \mathrm{FKN} \_A V E R+0.230 \times$ PA_AVER $+0.231 \times$ BI_AVER $\times$ FKN_AVER

\section{Result discussions}

\section{The intention to buy life insurance}

Acceptance of hypotheses $\mathrm{H}_{1}, \mathrm{H}_{2}, \mathrm{H}_{3}, \mathrm{H}_{4}, \mathrm{H}_{5}$ indicates that the two variables of financial knowledge and attitude towards the purchase of life insurance are the mostly influence variables on the intention to buy life insurance (beta FKN 0.455). This result is also consistent with the results of Luciano et al. (2015) when they argued that the demand for insurance increased with the understanding of financial or educational level. This result is also consistent with current practice when the level of awareness about insurance products in Vietnam is still very low, compared to other countries in the region. Therefore, insurance enterprises need to strengthen communication in order to raise customers' awareness and understanding. In addition, the influence of insurance attitude on buying intent is also very positive with a beta of 0.237 . This result is also like the results of studies of Brahmana et al. (2018), Sayin (2003), Ogenyi Ejye and Owusu-Frimpong (2007) in developing markets due to limited attitudes of people and life insurance. They tend to choose alternative forms of savings instead of life insurance. Meanwhile, in developed countries when insurance culture became popular, the influence of this variable was negligible (Fletcher and Hastings, 1984). The second determinant that belongs to cognitive behavioral control is the ability to access the product, which means that for every 1 unit increase in product access, there is an increase of 0.17 units intends to buy insurance and 0.23 the unit of decision to buy insurance. In Vietnam, when the awareness and understanding of insurance is not high, 
the rate of buying insurance depends largely on the network of distribution channels of enterprises such as agents, brokers or banks. However, the impact of this factor is not much in developed countries with higher insurance culture. This result is consistent with many previous studies in Vietnam such as Tien Dung Nguyen et al. (2015) when determining determinants such as consultants, insurance distribution channels and market entry barriers can influence on the purchase of life insurance. This suggests to enterprises increasing the product accessibility through developing or completing traditional distribution channels such as agents or promoting new distribution channels such as Bancassurance or online distribution channels. The impact of risk perception on insurance intention is measured with a beta of 0.186 . people with a higher level of risk perception are more likely to buy life insurance (Saibaba et al., 2002; Jacobs-Lawson \& Hershey, 2005). The effect of the subjective norms at 0.097 is insignificant, which can be explained by the fact that life insurance products are individual financial service products, which are not like tangible and informative products. Therefore, the impact of other people's opinions is not too great. However, it still has a positive impact on customers' buying intent. As insurance products are intangible, sharing the feelings of others will have a great influence on the intention of consumer behavior instead of the ability of customers to perceive themselves. Also, insurance products are unexpected products, so experience sharing by other customers in the past will create positive or negative effects on potential customers. Hence, the development and improvement of after-sales customer care is very important to enhance loyalty as well as the ability to spread information of existing customers to potential customers.

\section{The life insurance buying behavior}

The regression results show that the intention, financial knowledge, product accessibility have a relatively $\mathrm{s}$ impact on the behavior of buying life insurance. In which, both financial knowledge and product access have a correlation coefficient of 0.23 . This is entirely consistent with the reality of Vietnam's insurance market when insurance contracts are purchased passively by distribution channels such as agents (consultants), who advise and persuade, not by buyers actively seeking products. The process of purchasing insurance products is different from that of a normal product because the terms and contents of insurance are complex and easy to get confused. Insurance products are tailored-designed for each individual, not a commercial product, so the purchase process requires certain knowledge and this process must be supported by intermediaries such as financial advisors. Acceptance of the $\mathrm{H}_{10}$ hypothesis suggests that the regulatory variable is a financial knowledge that drives the process from intent to behavior. Accordingly, when people were intending to buy, the increase in a unit of financial knowledge has the effect of promoting the intention of buying into actual buying behavior with the impact of increasing 0.23 units of practical behavior. The regression results also show that, when the intention to buy insurance with s financial knowledge exists, customers can find the appropriate distribution channels and access insurance. Therefore, the decision to buy insurance will not depend much on this determinant. Meanwhile, in the context of other determinants are constant, the impact of product accessibility on purchasing behavior is still recorded with an impact level of 0.23 . This can be understood as follows: when the customer has no intention of buying yet, he/she meets the appropriate consultants and distribution channels to convince customers to buy life insurance without even knowing the product. In the opposite case, when the customer has little knowledge about the product and there is an intention to buy, often they search for the right information channels and access to appropriate products in order to turn their intention into action. Therefore, at this stage, the impact of the product access determinant is not as much important as before. Even with the absence of the distribution channel, customers can actively search for appropriate distribution channels based on their knowledge, so the impact of the distribution channel element or access to products in this period does not mean much. Thus, the summary of research results shows that although the level of impact of the determinants is different in different circumstances, the two cognitive variables controlling behavior are still significant to the decision to buy insurance. Therefore, insurance companies need to promote communication activities to raise awareness and understanding for customers about life insurance products as well as enhance product accessibility through different measures, such as: promoting agent quality management in life insurance businesses; establish channels to receive multi-dimensional feedbacks on the quality of agency activities; Standardize the system of standards for insurance agents / consultants as well as complete and develop the distribution channel system to increase product accessibility to customers. In addition, in the era of Industrial Revolution 4.0, all potential customers (teenagers) are intimately connected to the online world and very familiar with the media. social, digital as well as technology. As a result, encouraging and developing other information exchange channels to understand the psychology and needs of potential customers also create better conditions for insurance companies to build insurance products which are more suitable to the needs of each participant. Moreover, unlimited geographical channels also help insurers exchange information and take better care of their customers.

\section{References}

Ajzen, I. (1985). From intentions to actions: A theory of planned behavior. Action control. Springer.

Ajzen, I. (1991). The theory of planned behavior. Organizational behavior and human decision processes, 50, $179-211$.

Ajzen, I. (2006). Constructing a theory of planned behavior questionnaire. Amherst, MA.

Ajzen, I. \& Cote, N. G. (2008). Attitudes and the prediction of behavior. Attitudes and Attitude Change, 289-311.

Ajzen, I. \& Fishnein, M. (2005). The influence of attitudes on behavior. The handbook of attitudes, 173, 31.

Baek, E. \& Devaney, S. (2005a). Human capital, bequest motives, risk, and the purchase of life insurance. Journal of Personal Finance, 4 , $62-84$.

Baek, E. \& Devaney, S. (2005b). Human capital, bequest motives, risk, and the purchase of life insurance.

Beck, T. \& Webb, I. (2003). Economic, demographic, and institutional determinants of life insurance consumption across countries. The World Bank Economic Review, 17, 51-88. 
Berekson, L. L. (1972). Birth order, anxiety, affiliation and the purchase of life insurance. Journal of Risk and Insurance, 39(1), 93-108.

Brahmana, R., Brahmana, R. K., \& Memarista, G. (2018). Planned behaviour in purchasing health Insurance. The South East Asian Journal of Management.

Campbell, R. A. (1980). The demand for life insurance: An application of the economics of uncertainty. The Journal of Finance, 35, 11551172.

Carson, J. M. \& Forster, M. D. (2000). Suitability and life insurance policy replacement: An analytical tool. Journal of Insurance Regulation, $18,427$.

Chen, L. (2009). Online consumer behavior: An empirical study based on theory of planned behavior. 3355613 Ph.D., The University of Nebraska - Lincoln.

Cohen, J. (1988). Statistical power analysis for the behavioral sciences. $2^{\text {nd }}$ ed. Hillsdale, NJ: erlbaum.

Fischer, S. (1973). A life cycle model of life insurance purchases. International Economic Review, 14, 132-152.

Fishbein, M. \& Ajzen, I. (1980). Predicting and understanding consumer behavior: Attitude-behavior correspondence. Understanding Attitudes and Predicting Social Behavior, 148-172.

Fletcher, K. P. \& Hastings, W. J. (1984). Consumer choice: a study of insurance buying intention, attitudes and beliefs. The Service Industries Journal, 4, 174-188.

Garman, E. \& Forgue, R. (2006). Personal finance. Boston: Houghton Mifflin Company.

George, D. \& Mallery, P. (2016). IBM SPSS statistics 23 step by step: A simple guide and reference, New York, Routledge.

Hair, J., Anderson, R., Babin, B. \& Black, W. (2010). Multivariate data analysis: A global perspective : Pearson Upper Saddle River. NJ.

Hammond, J. D., Houston, D. B., \& Melander, E. R. (1967). Determinants of household life insurance premium expenditures: An empirical investigation. Journal of Risk and Insurance (pre-1986), 34(3), 397.

Hastings, W. J. \& Fletcher, K. P. (1983). The relevance of the Fishbein model to insurance buying. The Service Industries Journal, 3, 296307.

Hayes, A. F. (2012). My macros and code for SPSS and SAS. URL: http://afhayes.com/spss-sas-andmplus-macros-and-code.html

Hwang, T. \& Gao, S. (2003). The determinants of the demand for life insurance in an emerging economy-the case of China. Managerial Finance, 29, 82-96.

ISI 2019. THE ANNUAL REPORT OF VIETNAM INSURANCE MARKET 2018. In: AUTHORITY, I. S. (ed.) 5 November ed.: Insurance Supervisory Authority.

Jacobs-Lawson, J. M. \& Hershey, D. A. (2005). Influence of future time perspective, financial knowledge, and financial risk tolerance on retirement saving behaviors. Financial Services Review, 14, 331.

Jacoby, J. \& B. Kaplan, L. (1972). The Components Of Perceived Risk.

Kasule, S. (2011). Consumer attitudes, financial literacy and consumption of insurance in Kampala, Uganda. Makerere University.

Lewis, F. D. (1989). Dependents and the demand for life insurance. American Economic Review, 79, 452-467.

Li, D., Moshirian, F., Nguyen, P. \& Wee, T. (2007). The demand for life insurance in OECD countries. Journal of Risk and Insurance, 74, 637-652.

Luciano, E., Outreville, J. F. \& Rossi, M. (2015). Life insurance demand: evidence from Italian households; a micro-economic view and gender issue.

Mekonin, A.N. (2018). Application of a probit model in assessing determinants of formal financial saving behavior of rural households: The case of Sinana District, Ethiopia. Journal of Economics and Development, 20(2), 94-106.

Morgenstern, O. \& Von Neumann, J. (1953). Theory of games and economic behavior. Princeton university press.

Ogenyi Ejye, O. \& Owusu-Frimpong N. (2007). Life insurance in Nigeria: An application of the theory of reasoned action to consumers' attitudes and purchase intention. The Service Industries Journal, 27, 963.

Omar, O. E. (2007). The retailing of life insurance in Nigeria: an assessment of consumers' attitudes. The Journal of Retail Marketing Management Research.

Saibaba, R., Prakash, B. \& Kalyani, V. (2002). Perception and attitude of women towards life insurance policies. Indian Journal of Marketing, 32, 10-12.

Sayin, A. (2003). Consumer attitudes and behavioural intentions towards life insurance in Turkey: an application of the theory of reasoned action. M. Sc. Dissertation submitted to the Faculty of Business, Computing and Information Management, London South Bank University.

Showers, V. E., \& Shotick, J. A. (1994). The effects of household characteristics on demand for insurance: A tobit analysis. Journal of Risk and Insurance (1986-1998), 61(3), 492.

Starmer, C. (2000). Developments in non-expected utility theory: The hunt for a descriptive theory of choice under risk. Journal of Economic Literature, 38, 332-382.

Thuy Tien Ho (2007). Developing Vietnam's life insurance market in the period of international economic integration'. PHD Thesis, , University of Economics Ho Chi Minh city.

Tien Dung Nguyen, Pham, N. T. A. \& Pham, T. M. (2015). The determinants of intention to buy retirement plans of HCMC residents. Science and Technology Development Journal, 18, 45 -54.

Trong Thao Phi (2003). Solutions to meet the potential needs of life insurance in Vietnam. PHD Thesis, Academy Of Finance.

Vu Hung Nguyen, Thi Bao Thoa Hoang \& Nguyen, H. C. (2016). Green consumption: Factors that promote the relationship from intention to behavior. Journal of Economics \& Development, 233, 121- 129.

Yaari, M. E. (1964). On the consumer's lifetime allocation process. International Economic Review, 5, 304-317.

Yaari, M. E. (1965). Uncertain lifetime, life insurance, and the theory of the consumer. The Review of Economic Studies, 32, 137-150.

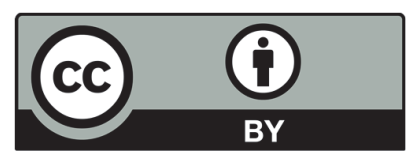

(C) 2020 by the authors; licensee Growing Science, Canada. This is an open access article distributed under the terms and conditions of the Creative Commons Attribution (CC-BY) license (http://creativecommons.org/licenses/by/4.0/). 